\title{
An economic perspective on Brexit
}

\author{
Christian Soegaard (C.Soegaard@warwick.ac.uk) \\ University of Warwick, United Kingdom \\ Philipp J.H. Schröder (psc@econ.au.dk) \\ Aarhus University, Denmark
}

\begin{abstract}
"Regrettably, the uninformed observer may misjudge the development of the UK economy in the years to come. Conceivably, in the short run the Island-Economy strategy might pay off. It would be almost unbearable if public opinion - in the UK and other European countries - takes such short-run developments as evidence for the economic wisdom of Brexit." (Soegaard and Schröder, in this commentary)
\end{abstract}

There is overwhelming consensus that Britain will experience an adverse negative economic impact following its decision to leave the European Union, and in particular by leaving the bloc's Single Market. This is because Britain will lose out on important economic benefits resulting from well-established economic beliefs that more open economies that trade and invest with one another are better off. We argue, however, that for Britain there may be a silver lining with a bitter taste: if Britain succeeds in becoming an "island economy" with low taxes and little regulation it may nevertheless be able to attract investment and create jobs and growth. Yet this is likely to lead to beggar-thyneighbour policies in which other EU countries break out and start competing for the same benefits, leaving everyone worse off.

\section{The origins of an awkward relationship}

The story of the European Union has always been a political project propelled forward by economic win-win reasoning. This applies from the very first step, the establishment of the European Coal and Steel Community (ECSC) in 1951. This first effort of European integration - still very much in the shadow of the Second World War - laid the two guiding principles that matter until today: supranationalism and mutual economic benefits. Why the United Kingdom stayed outside the ECSC is a question for historians, but from an economic point of view the ECSC was for the UK economy as meaningful as bringing coal to Newcastle. Subsequently, the UK continued to stay outside the European integration project for the next decades - but less and less by choice.

The economic backdrop for the first two decades of this non-relationship is of course the dramatic relative economic decline of the UK economy (see Figure 1). Before and during the Second World War the UK was still an economic super power, with strong Commonwealth of Nations trade relations and the British pound still a vehicle currency of international commerce. The memory of that legacy suggested both for continental Europe, but not least for Britain's political ambitions, that the UK was a global economic player. Of course the 1950ies and 1960ies subsequently proved that assumption wrong. Over these decades UK foreign trade oriented increasingly to the growing Western European economies, and made it far more like its European peers. 


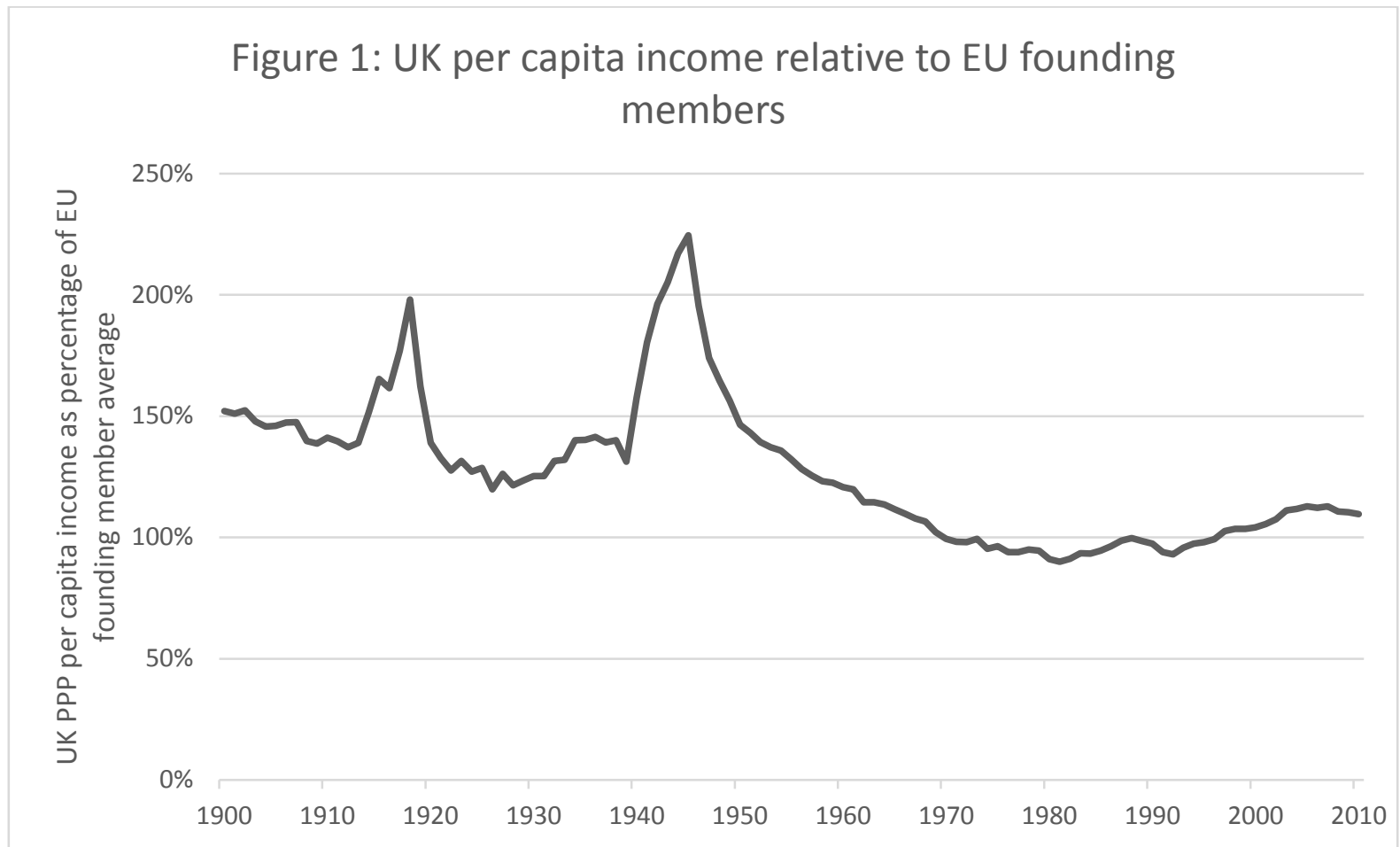

Note: Authors' calculation based on Geary-Khamis international dollar (base year 1990), purchasing power parity (PPP). ${ }^{1}$ Founding member group is the unweighted average of Belgium, France, Germany, Northern Italy and the Netherlands. Source: Maddison Project (2013).

As a result, unlike today, where the UK is trying to find ways to drag herself out of the EU, in the post-war years the UK was trying to find a way in. These efforts became more important, as Continental Europe's Economic integration gained momentum. It became clear that Britain was losing out on economic benefits. In particular, the landmark of the signing of the Treaty of Rome in 1956 between six founding European nations, which established the European Economic Community is a case at hand. This treaty obligated its signatories to gradually reduce customs duties and to establish a customs union with common external tariffs. The idea was to create an economic community to increase trade and investment amongst its members. This would produce the fundamental gains from trade as identified by Adam Smith in 1776 in opposition to the Mercantilist establishment, that were in the post-war period understood to drive prosperity for all participating nations.

Britain's pleas to enter the club were met with substantial opposition. In 1963, French President Charles De Gaulle vetoed the British application for entry into the European Economic Community, declaring "L'Angleterre, ce n'est plus grand chose" (England is not much anymore). It was not until 1973 that Conservative Prime Minister Edward Heath was able to take Britain in. It was mainly the Tory party which was keen to integrate the British economy with the European, because of a desire to break down barriers to trade between the nations of Europe and to create a tariff-free market. The EEC was 'too capitalist' to persuade many labour MPs to join Europe and to silence a loud group of anti-Europe Labour backbenchers, Labour Prime Minister Harold Wilson held a

\footnotetext{
${ }^{1}$ Comparison in Geary-Khamis international dollars and purchasing power parity (PPP) allows us to conduct a comparison across time and across countries, i.e. in real terms. In particular this measure avoids the pitfalls associated with inflation over time, and differences in national price levels. For example, if prices for non-tradable consumer goods such as renting a flat have different price levels in two different countries a PPP comparison corrects for these differences.
} 
referendum on membership in 1975. A decisive majority of Britons voted yes (i.e., voted to stay in the EEC), giving the Prime Minister a strong mandate to make Britain a powerful and influential member of the EEC.

The relationship between Britain and Europe, however, becomes more awkward as the degree of political integration between Britain and the continent intensifies. In 1987 the Single European Act is signed, and the Maastricht Treaty is signed in 1991 with Prime Minister John Major obtaining an opt-out on the single currency. As political integration intensifies and more powers shift from the nation states to Europe, the political climate changes: while the Tory party was the party which traditionally favoured the EU, the Labour party now becomes the EU's friend in the House of Commons, in particular with the EU legislating on climate policy and workers' rights. A rebellion begins in the Tory party under the leadership of John Major, and the Tory party becomes deeply divided over the issue. In particular, with an EU-sceptic Tory membership, it becomes hard for those tory members seeking to reach the top to sell Europe in a positive light, even if they are keen supporters of a Britain in Europe. Yet, in that very period of growing EU scepticism, the economic realities for the UK in the 1980s and forward showed rapidly increasing integration and not least specialisation, such as the rise of the City of London for financial services.

More recently, that is, since the turn of the century, European integration also brought with it an increase in net migration to the UK. The flows of net migration have mainly been characterised as an East to West phenomenon, whereas labour flows within the Western European countries remain low.

\section{The 2016 referendum: political versus economic logic}

The referendum which was held in June 2016 was not unlike the one back in 1975. Prime Minister Theresa May's predecessor David Cameron was likely motivated by a desire to obtain a democratic mandate for continued membership of the EU from the people of Britain. Moreover, he was worried about Conservative backbenchers defecting to the farright United Kingdom Independence Party (UKIP). With this in mind, David Cameron essentially gambled the future of Britain's relationship with Europe and the rest of the world. This gamble turned out to backfire and there is overwhelming consensus amongst economists that Brexit will harm the economy.

Arguments during the referendum campaign focussed on many issues, but there seems to be a general agreement that the main issue which may have swayed many voters towards a vote to leave is that of immigration. Demographics and migration are at large economic forces affecting the pool of labour available to create output and value added in a given territory. In this respect migration - and the economic gains from migration is not different from that of the free movement of goods or firms across borders. However, changing the demographic composition of a country has a stark non-economic dimension. A large proportion of voters subscribe to the belief that foreign labour depresses wages and reduces employment of native labour, although there is not much evidence to back up such claims. Albeit, a recent Bank of England Working Paper finds that there is a negative but small impact of the immigrant to native labour ratio on average British wages; see Nickell and Saleheen (2015). In Figure 2 we plot the share of the migrant population as a percentage of total population in the UK and in the six founding EU members. Clearly, this share has been increasing since 1960, and marginally more so in the UK in the five years to 2015, although the slower growth in this trend amongst the EU founding members was driven mainly by somewhat below average migration to Italy and France. 
Figure 2: Share of migrant population as a percentage of total - Founding EU members and the United Kingdom

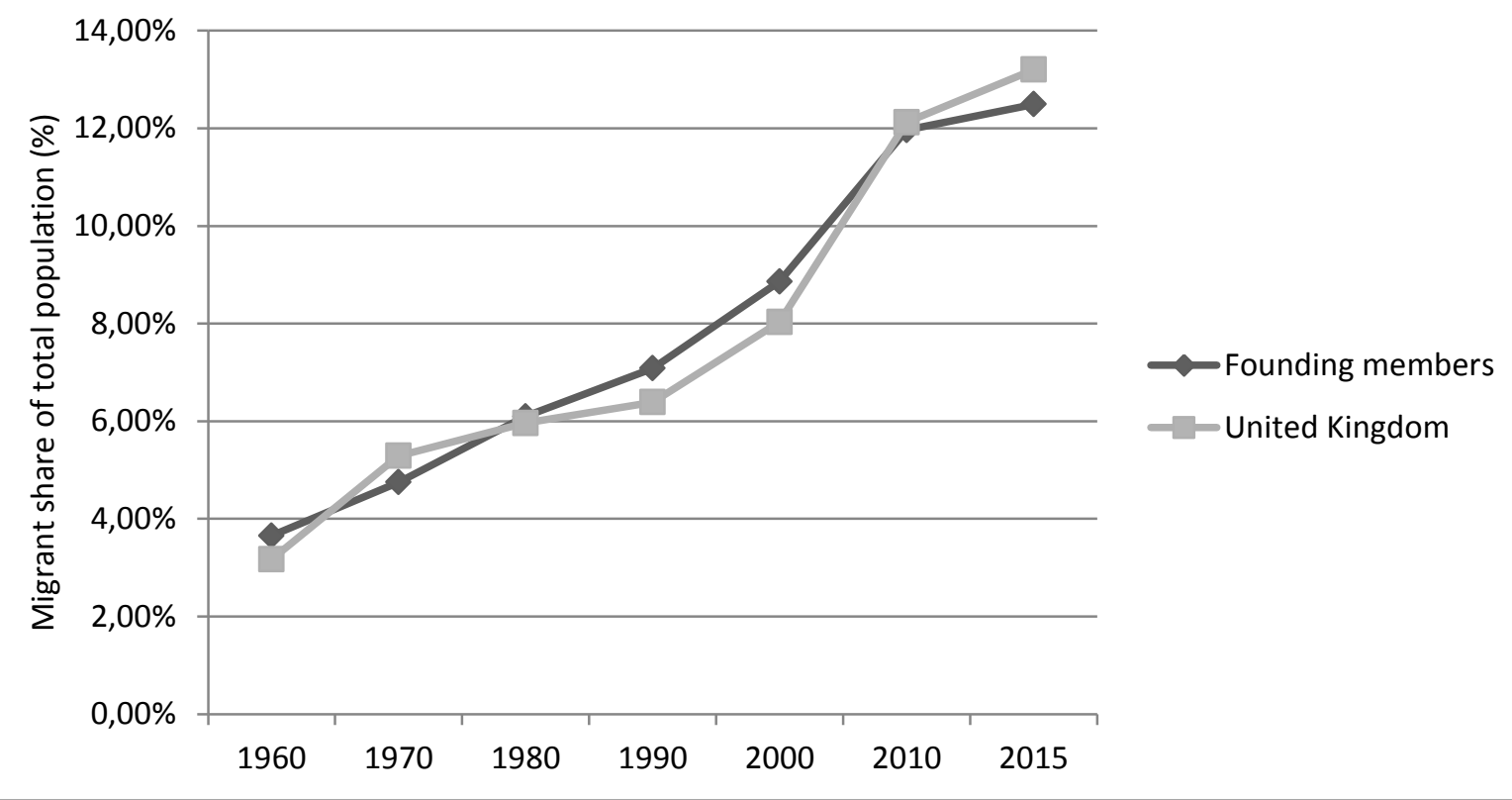

Note: Share of total migration includes all migration (EU and non-EU). Founding member group is the weighted average of Belgium, Luxembourg, France, Germany, Italy and the Netherlands. Source: Migration Policy Institute (2016).

Another important issue - despite the absence of an economic rationale - centred around sovereignty, that is, Britain's ability to determine its own laws, and identity. A vote to leave the European Union was not supported by economists in general. In fact, more than $90 \%$ of economists recommended a vote to remain. In fact, it is worth noting that there were more Nobel Prize winning economists in the lobby group Economists for Remain (12 in total) then there were economists in Economists for Brexit (8).

So why is the economic case for the benefits of economic integration (or rather the costs of Brexit) so clear-cut? Broadly speaking, economists distinguish between the short run and the long run impact of Brexit. Should there be a short run cost associated with leaving the European Union, such a loss can be justified only if the long run gains are sufficient to counter the short run losses. There is overwhelming consensus, however, that both the short run and long run impact of Brexit represent substantial losses to the British economy. In the short run, the costs are associated with the uncertainty related to the degree of access which Britain is going to have to Europe's Single Market and to the rest of the world. The first negative responses that have been observed on the stockmarket and currency exchange in response to the Brexit vote are just that. Investors are likely to put off investment until Britain's new relationship with Europe becomes clearer. These costs, however, are associated with Britain changing its status in Europe, or in economics jargon, moving from one equilibrium to another. While these costs should not be underestimated, and may affect the British economy for decades to come, the potential long run costs associated with losing access to the world's largest market could be even greater and affect the British people for generations. It is this long-run perspective that drives the large consensus among economists.

The argument that a country losing its market access will be worse off in the long run relies on well-established economic findings, both empirically and theoretically, that more open economies which trade and invest with other nations are better off. Trade 
economists have identified at least three types of gains from trade. The first type concerns the gains from specialisation. This unique type of gain from trade was established by Adam Smith (1776) several centuries ago. The idea is that countries should increase the production of goods and services for which they hold a comparative advantage, and then exchange the difference on international markets. Having a comparative advantage in a particular good implies that the opportunity cost of producing it is lower. In other words, a country gives up less of "all other goods" to produce it. While this type of gain from trade is well established, it is widely believed that in the developed world, the nature of the gains from trade is driven by economies of scale. The ability of, say, a car manufacturer in one country to be able to expand production into other markets allows the exploitation of scale economies, and confers a welfare gain on consumers in terms of increased variety. Krugman (1981) identified this type of gain from trade, and Melitz (2003) extended this type of model to show that in addition to the gain from increasing scale, international trade leads to a selection process in which smaller and less productive firms drop out in favour of larger firms with the end result being greater productivity in the market as a whole. The third gain which also characterises trade between developed countries is related to increased competition (so called pro-competitive effects), which is an important gain to consumers. By increasing competition, international trade is likely to erode domestic mark-ups and drive out monopolies.

\section{In danger of extinction: deep integration}

The three forces of gains from trade (specialisation, scale and pro-competitive effects) depend crucially on the depth of integration. While the removal of tariff and customs barriers might facilitate some goods trade, ample non-tariff barriers remain that hinder the actual economic activity from crossing borders. For example, divergent product standards, exchange rate risks, health and safety rules or simply red-tape can be as sizable a barrier to trade as any tariff. Empirically, today, economists agree that non-tariff barriers are far more important than tariff barriers. Deep integration tackles exactly such non-tariff barriers. It is the mutual recognition of professional authorisations, common product safety standards or level-playing field public procurement rules that are the driving force of the deep integration the EU has marched forward with in recent years. This is particularly important for service sector trade and many of the higher value added industries, such as pharma. Being part of the European Single Market ensures that the countries can benefit from all three types of gain from trade. The EU has eliminated tariff-barriers to trade between its members allowing EU countries to specialise production, exploit economies of scale, and break down domestic market power. More importantly, given the ability of the EU to make law through its institutions (EU Parliament and Council of Ministers), it is able to harmonise product standards and regulation across all its member countries. The issue here is the access to the Single Market which membership of the EU affords. The ability of British firms to freely invest in and trade with 27 other European nations is a substantial benefit to the British economy. Should Britain opt for the so called "Hard Brexit" in which it completely withdraws from the Single Market, it is likely that some firms will relocate their production to continental Europe in order to obtain market access. Such moves will inevitably cost jobs and growth for the economy.

Many brexiters argue that Britain will be able to sign trade agreements with non-EU countries once outside the union. However, given that trade with any non-EU country is substantially lower than with the 27 other EU countries, it is unlikely to yield significant welfare benefits. Moreover, due to the sequential nature of trade negotiations, it would 
take Britain decades to fully implement such agreements. And even if the agreements are negotiated, they are not likely to be as "deep" as the trade integration within the Single Market. Most importantly different sectors will be affected differently. While it may be conceivable to maintain zero tariff trade agreements, it is hard to imagine that the UK will be able to buy in on issues such as safety standards, or professional authorisations. This implies that, for example, the service sector, and not least the financial service sector of banking and insurance will be hit disproportionately hard. Importantly, due to the economic mechanisms of win-win in trade, this also has severe costs for continental Europe. Seeing less of the firms and business drive of the City of London in the various capitals of Europe, means that national commercial banks face less competition, in turn reducing pro-competitive gains from trade. As much as economic integration is a win-win for the participating nations, exit (not least Brexit) is a lose-lose for everyone.

\section{A silver lining with a bitter taste}

Might there then be some sort of silver lining for Britain in the long run? We believe that outside the Single Market, it is likely that Britain will need to find alternative ways to attract investment and to induce firms to locate in the British economy. As such, the British government may see no other option than to lower business taxes (corporate taxation for example), and to deregulate its services and manufacturing sectors to provide a cost advantage to firms choosing to locate in Britain. In a way, it would become a tax shelter, or an island economy similar to the Cayman Islands or Panama. Such a move, however, is unlikely to go unpunished by the EU which would face a competitive disadvantage. The EU would likely (and perhaps justifiably) respond by restricting access to the Single Market, or by engaging in a predatory tax and regulation war which would restore its relative competitive advantage. Thus, whether Britain would benefit from becoming an "island economy" depends on the extent to which Britain can compensate, in the form of tax advantages and deregulation for domestic firms, for the restricted market access it is going to face from the 27 remaining members of the EU. In this perspective, the initial 15\% devaluation of the British pound in the aftermath of the UK referendum is a case at hand that gives a taste of what is to come. The devaluation of the pound might not stimulate UK export as Brexiters might have hoped. This is because Britain is specialised in exports that are less price sensitive (services in particular); as such a depreciation of Sterling does little to boost its exports. Likewise, British consumers will find inflated goods prices which ultimately will reduce their purchasing power.

Britain's success outside the Single Market will have an impact on the desirability of the remaining EU members' desire to stay in the bloc. If Britain can become a successful island economy, many other current members of the EU may be tempted to join Britain outside the union. However, this is likely to create a free-rider problem in the following sense: while it may be advantageous for one country, it is doubtful if the advantages would persist if several countries attempted the same strategy. Britain's potential advantage from becoming an "island economy" stems from its ability to avoid adhering to the rules of the Single Market while every other economy does. This would give rise to a free-rider problem in which countries would seek to leave the union to enjoy the benefits of free play. When all countries do so, however, they will all be competing for the same benefits which ultimately would leave all countries worse off.

The scenario in which Britain pursues policies which would lead it to become an "island economy" is not unlikely in the current political climate. The Labour party is currently under the weak leadership of Jeremy Corbyn who seemed to show only a lukewarm support for the Remain campaign during the referendum. Mr Corbyn is unlikely to win the general election which is due in 2020, and for this reason, the Conservative 
backbenchers may see this situation as giving them a mandate for a "Hard Brexit" and to implement this sort of deregulated low tax haven which they have been advocating for years.

The vote for Brexit is a tragedy as seen from an economic perspective, rolling back decades of economic integration. It is difficult to see a silver lining in this chaotic environment. Britain is likely to lose out on important long-term benefits from membership of the Single Market, and the need to find alternative ways to make Britain attractive to invest in will result in beggar-thy-neighbour policies. The loser from all this is likely to be us all.

Regrettably, the uninformed observer may misjudge the development of the UK economy in the years to come. Conceivably, in the short run the Island-Economy strategy might pay off. It would be almost unbearable if public opinion - in the UK and other European countries - takes such short-run developments as evidence for the economic wisdom of Brexit. The economic truth is that while free-riding might work for one, it cannot work for everyone.

\section{References}

Krugman, Paul (1981), Intraindustry Specialisation and the Gains from Trade. Journal of Political Economy, Vol. 89 (5): 959-973.

Maddison-Project (2013). New Maddison Project Database. http://www.ggdc.net/maddison/maddison-project/home.htm.

Melitz, Marc J. (2003), The Impact of Trade on Intra-industry Reallocations and Aggregate Industry Productivity. Econometrica, Vol. 71: 1695-1725.

Migration Policy Institute (2016), International Migrant Population by Country of Destination, 1960-2015. International Migration Statistics. http://www.migrationpolicy.org.

Nickell, Stephen and Jumana Saleheen (2015), The impact of immigration on occupational wages: evidence from Britain. Bank of England Staff Working Paper. No. 574. 